\title{
A New Cu(II) Complex of PAMAM Dendrimer Modified with 1,8-Naphthalimide: Antibacterial and Anticancer Activity
}

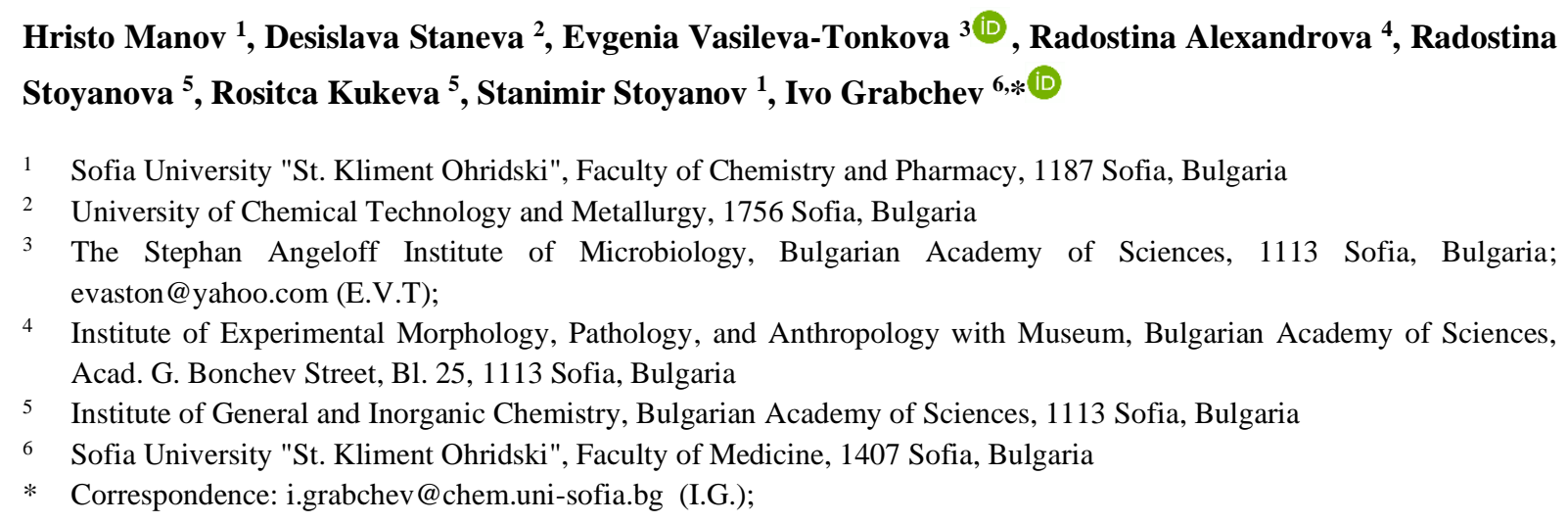

Received: 6.07.2021; Revised: 22.08.2021; Accepted: 26.08.2021; Published: 19.10.2021

\begin{abstract}
A new fluorescent PAMAM copper complex $\left(\left[\mathrm{Cu}_{2}(\mathrm{D})\left(\mathrm{NO}_{3}\right)_{4}\right]\right)$ has been synthesized and identified. The formation of the complex has been investigated by fluorescence spectroscopy which revealed two copper ions to be bound to the dendrimer ligand. That has also been confirmed upon subjecting the solid copper complex to electron paramagnetic spectroscopy. The antimicrobial activity of the copper complex against Gram-negative bacterium Pseudomonas aeruginosa in light and the dark has been studied. The results demonstrate an increase in its activity when irradiated with daylight. This activity of the copper complex is retained even after being loaded onto a cotton cloth. The antitumor activity of the copper complex and dendrimer ligand against triple-negative breast cancer MDA-MB231 cells has been investigated as well.
\end{abstract}

Keywords: metallodendrimers; 1,8-naphthalimide; antimicrobial activity; antitumor activity; antibacterial textile

(C) 2021 by the authors. This article is an open-access article distributed under the terms and conditions of the Creative Commons Attribution (CC BY) license (https://creativecommons.org/licenses/by/4.0/).

\section{Introduction}

With the development of synthetic organic chemistry, new opportunities have been created to develop and study novel three-dimensional macromolecules, the so-called dendrimers. They are characterized by monodispersity and perfectly branched symmetrical structure. Combining the properties of low- and high molecular substances, dendrimers have been enjoying a constantly growing interest [1-4].

There are a number of examples of successful use of dendrimers as ligands for the production of metallodendrimers, which have demonstrated very good microbiological and antitumor activity [5-7]. Biologically important metal ions such as $\mathrm{Cu}(\mathrm{II}), \mathrm{Co}(\mathrm{II}), \mathrm{Zn}$ (II), $\mathrm{Fe}$ (II), $\mathrm{Fe}$ (III) play a key role in the structural organization of enzymes and biologically active substances in living organisms. Therefore, in recent years, much research has been focused on preparing metal complexes with different organic ligands, aiming to improve existing 
chemotherapeutics' action [8-10]. The design, synthesis, and study of new ligands and their metal complexes are of interest as their biological activity depends on the nature of metal ions and the chemical structure of the ligands and the type of bond occurring between them.

Fluorescent dendrimers containing chromophore fragments at specific, predetermined positions of the molecule have been developed. The tailoring has yielded new properties and new areas of their application in chemistry, biology, pharmacy, nanomedicine, and others. Modification of PAMAM and PPA dendrimers with organic fluorophores such as 1,8naphthalimide [11,12], rhodamine [13], benzanthrone [14], acridine [15], 4-nitrobenzofurazan [16], curcumin [17] results in obtaining fluorescent dendrimers with very good photophysical characteristics. Our laboratory has been carrying out targeted research to elucidate the structure-property relationship of such photoactive dendrimers. Our previous research has shown, on the one hand, that such dendrimers can be used to detect metal ions and protons [11], and on the other hand, that they exhibit good antimicrobial [15,16,18-21] and antitumor activity [22].

Among the known fluorophores with well-defined biological activity, an important place is occupied by 4-substituted 1,8-naphthalimides due to the ability of 1,8-naphthalimide derivatives to interact with different biological systems through non-covalent interactions, such as $\pi$ - $\pi$ stacking. Hence, the wide biomedical interest in these compounds of high antitumor, antimicrobial, antiviral or anti-inflammatory activity [23-26].

Moreover, dendrimer molecules have a large number of closely related functional groups in their structure. If these groups are functionalized with biologically active substances, one can expect the dendrimer molecule to enhance its biological activity compared to that of low molecular weight compounds.

This study presents the synthesis and characterization of a new zero-generation polyamidoamine (PAMAM) dendrimer-based metallodendrimer modified with four 1,8naphthalimide fragments. Its antibacterial activity has been examined in the dark and upon irradiation with daylight. The experiments have been carried in solution and when loaded onto cotton fabric. The antitumor activity of the new metallodendrimer against triple-negative breast cancer MDA-MB-231 cells has also been studied.

\section{Materials and Methods}

The synthesis and the characterization of dendrimer D used as a ligand in this study were already described [27]. All methods used for the analysis and investigations are described in the Supporting information.

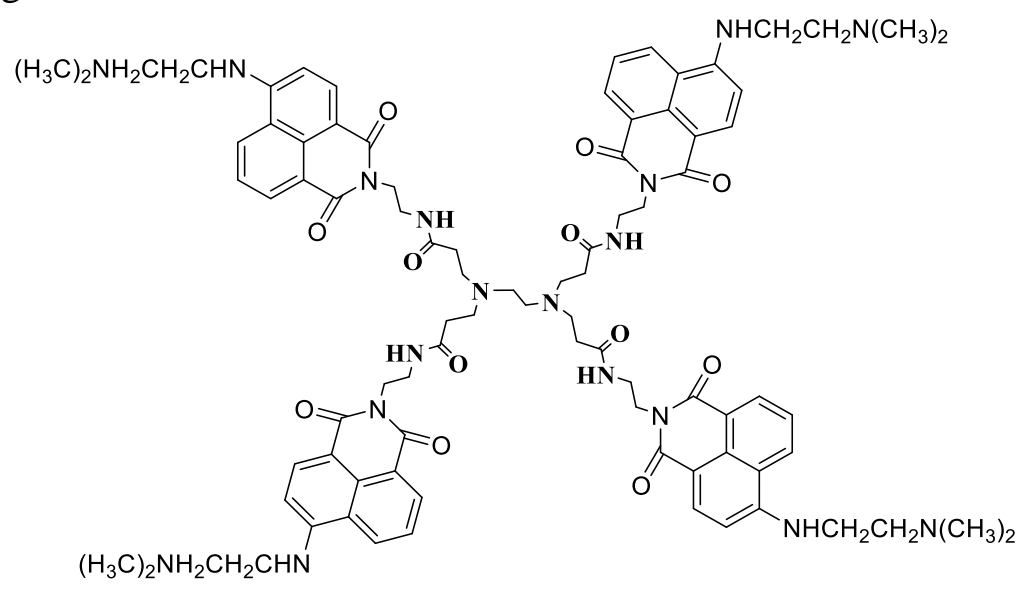

Scheme 1. Chemical structure of dendrimer D. 
2.1. Synthesis of $\mathrm{Cu}(\mathrm{II})$ complex of dendrimer $\mathrm{D}$ : $\left[\mathrm{Cu}_{2}(\mathrm{D})\left(\mathrm{NO}_{3}\right)_{4}\right]$.

Dendrimer D $(1.580 \mathrm{~g}, 0.001 \mathrm{M})$ was dissolved in ethanol, and copper nitrite $(0.751 \mathrm{~g}$, $0.004 \mathrm{M}$ ) was added under reflux. The reaction mixture was stirred for 3 hours. After cooling, the precipitate formed was filtered off, washed three times with $10 \mathrm{ml}$ of ethanol, and dried.

Yield: $(1.68 \mathrm{~g}, 86 \%)$

FTIR: $\mathrm{cm}^{-1}: 2928,2854,1635,1581,1547,1419,1395,1340,1241,1183,1035,774$, 757, 579, 498,

Analysis: $\mathrm{C}_{86} \mathrm{H}_{104} \mathrm{O}_{24} \mathrm{~N}_{22} \mathrm{Cu}_{2}(1955.2 \mathrm{~g} / \mathrm{mol})$ : Calcd C 52.78, H 5.32, N 15.75; Found C 52.89, H 5.40, N 15.78 .

\subsection{Treatment of the cotton fabric with dendrimer $\mathrm{D}$ and $\left[\mathrm{Cu}_{2}(\mathrm{D})\left(\mathrm{NO}_{3}\right)_{4}\right]$.}

A piece of cotton fabric $\left(140 \mathrm{~g} / \mathrm{m}^{2}\right)$ weighing $1 \mathrm{~g}$ was added to $10 \mathrm{ml}$ of DMF solution of dendrimer $\mathrm{D}(2.50 \mathrm{mg})$ and its $\mathrm{Cu}$ (II) complex at $40^{\circ} \mathrm{C}$. After $60 \mathrm{~min}$, the cotton sample was washed with distilled water and dried at room temperature. Fluorescent spectroscopy measurements showed that $2.2 \mathrm{mg}$ of (D) and $2.1 \mathrm{mg}$ of (copper complex) had been loaded onto the cotton surface.

\section{Results and Discussion}

\subsection{Chemical investigations.}

The synthesis of dendrimer D used as a ligand has been described previously [27]. The substituent at the $\mathrm{C}-4$ position of the 1,8-naphthalimide fluorophore structure $-\mathrm{NH}-\mathrm{CH}_{2} \mathrm{CH}_{2}$ $\left(\mathrm{NCH}_{3}\right)_{2}$ has been tailored to act as a receptor fragment in the formation of various biologically active metal complexes - such as Cu (II) Zn (II), Co (II), Fe (II), Fe (III) complexes, etc. Its main photophysical characteristics have been studied in organic solvents of different polarities. It has been shown that in non-polar media, the quantum efficiency of this dendrimer is much better expressed if compared to that in non-polar solvents [28]. In the presence of metal ions, the fluorescent intensity of dendrimer D is amplified several times, which is due to the quenching of the photoinduced electron transfer occurring from the distant nitrogen atom ($\left.\mathrm{N}\left(\mathrm{CH}_{3}\right)_{2}\right)$ to the fluorophore 1,8-naphthalimide system [29].

Studies have been performed to evaluate the effect that the concentration of $\mathrm{Cu}$ (II) ions has on the fluorescence intensity of dendrimer D. DMF has been used as a solvent since dendrimer $\mathrm{D}$ has a low fluorescence intensity $(\mathrm{FF}=0.11)$ [28]. On the other hand, copper nitrate dissolves very well in it, so does the copper complex formed. The fluorescence spectra of dendrimer $\mathrm{D}$ during its titration with $\mathrm{Cu}$ (II) ions in a concentration range up to $2.5 \times 10^{-5} \mathrm{M}$ is plotted in Figure 1A. The results show that the fluorescence intensity increases in proportion to the concentration of $\mathrm{Cu}$ (II) ions (Figure 1B), and saturation is reached at a 1:2 ratio between the dendrimer and copper complex $\mathrm{Cu}$ (II) ions. That illustrates how both $\mathrm{Cu}$ (II) ions from a complex with dendrimer D. As seen from Figure 1A, the position of the fluorescence spectrum does not change during the complex formation. That means the copper ions form a coordinate bond with the distant nitrogen atom $\left(-\mathrm{N}\left(\mathrm{CH}_{3}\right)_{2}\right)$ of the 1,8-naphthalimide structure, where one copper ion coordinates with two 1,8-naphthalimide fragments, as shown in Scheme 2. In this case, the ratio between the dendrimer and $\mathrm{Cu}$ (II) ions is 1:2. 

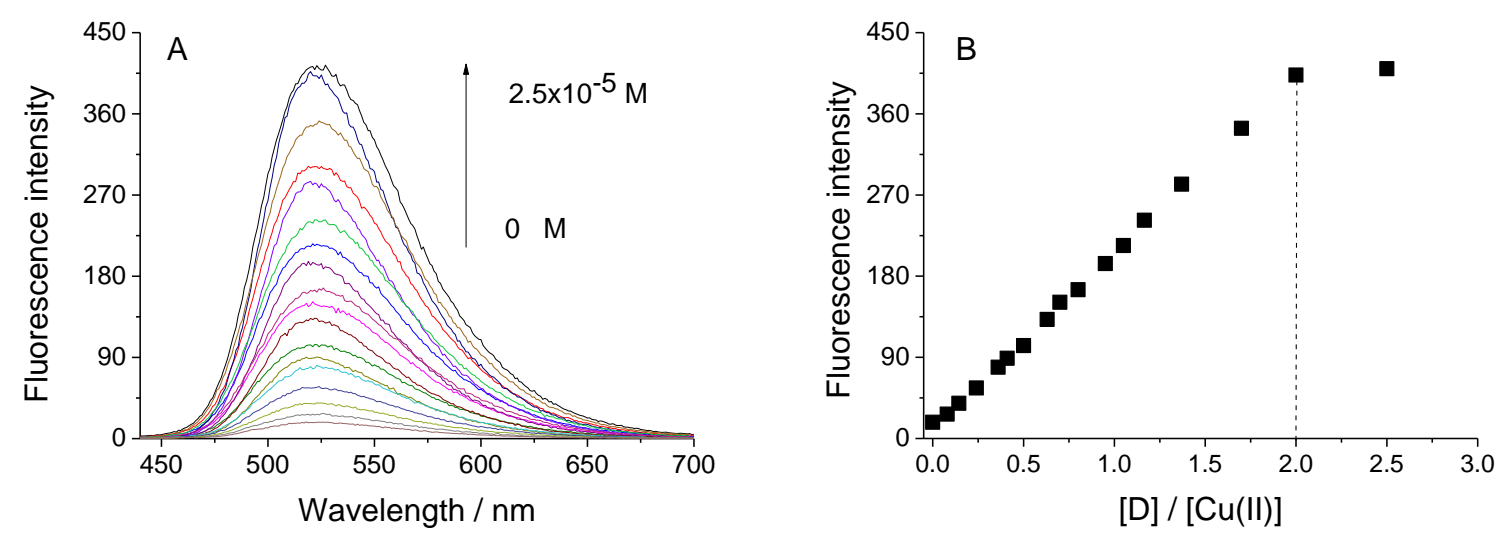

Figure 1. (A) Fluorescence spectra of dendrimer D in DMF solution $\left(\mathrm{c}=1 \times 10^{-5} \mathrm{M}\right)$ at different concentrations of $\mathrm{Cu}$ (II) cations (from 0 to $2.5 \times 10^{-5} \mathrm{M}$ ); (B) Dependence of the fluorescent intensity on the concentration of $\mathrm{Cu}$ (II) ions.

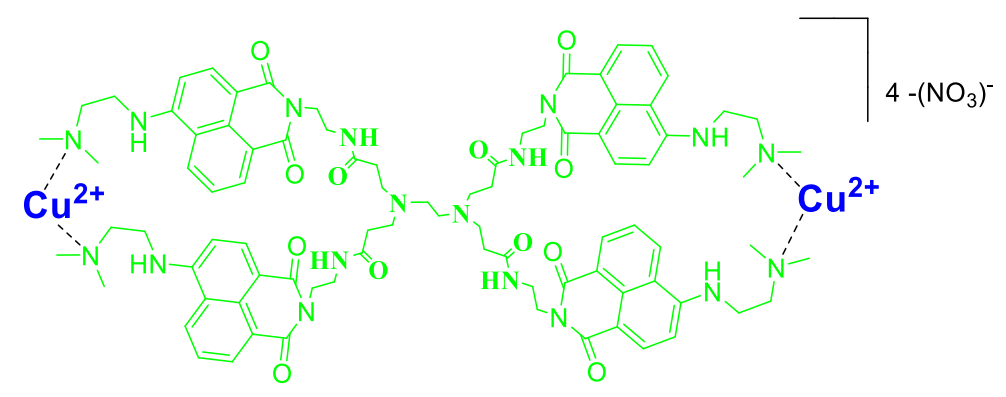

Scheme 2. Proposed structure of the complex of dendrimer D with $\mathrm{Cu}$ (II) ions $\left[\mathrm{Cu}_{2}(\mathrm{D})\left(\mathrm{NO}_{3}\right)_{4}\right]$.

\subsection{EPR investigations.}

The EPR spectrum of $\mathrm{Cu}$ (II) ions coordinated by dendrimer ligand D displays an anisotropic signal with the $g$-components of $g_{\|}=2.259$ and $g_{\perp}=2.030$, and a hyperfine constant of $\mathrm{A}_{\|}=16.5 \mathrm{mT}$. The $g$ - and A-components remain constant in the temperature range of $100-$ $295 \mathrm{~K}$. These EPR parameters are typical for $\mathrm{Cu}$ (II) ions located in a tetragonally elongated crystal field. The magnitude of the $g_{\|}$-component is relatively low, while the constant hyperfine $\mathrm{A}_{\|}$possess a relatively high value. Considering the Peisach - Blumberg diagram [30] of the relation between the values of $g$ - and $A$-components, it appears that $\mathrm{Cu}$ (II) ions are, most probably, coordinated through $\mathrm{N}$ and $\mathrm{O}$ atoms. Furthermore, the EPR spectrum allows evaluating the ratio between $\mathrm{Cu}$ (II) and dendrimer ligand $\mathrm{D}$. The calculation shows that two $\mathrm{Cu}(\mathrm{II})$ ions are attached to one dendrimer ligand.

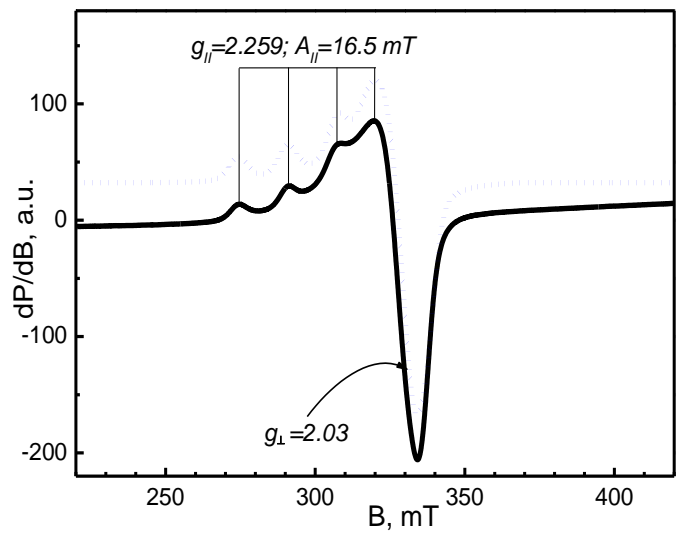

Figure 2. EPR spectrum of the complex between $\mathrm{Cu}$ (II) and D-ligand taken at $100 \mathrm{~K}$. The blue line corresponds to the simulated spectrum. 
3.3. Colorimetric characteristics of cotton fabrics treated with dendrimers $D$ and $\left[\mathrm{Cu}_{2}(\mathrm{D})\left(\mathrm{NO}_{3}\right)_{4}\right]$.

In order to obtain antibacterial textiles, $100 \%$ cotton fabrics have been treated with dendrimer $\mathrm{D}$ and its copper complex $\left[\mathrm{Cu}_{2}(\mathrm{D})\left(\mathrm{NO}_{3}\right)_{4}\right]$. The color characterization of the cotton fabrics has been conducted by determining the CIEab parameters $\left(\mathrm{L}^{*}, \mathrm{a}^{*}\right.$, and $\left.\mathrm{b}^{*}\right)$ and the respective chromaticity coordinates ( $\mathrm{x}$ and $\mathrm{y}$ ). The fabrics have been evaluated quantitatively and qualitatively by the corresponding color coordinates $\mathrm{L}^{*}, \mathrm{a} *, \mathrm{~b} *$, (equations 1-3):

$$
\begin{aligned}
& \mathrm{L}^{*}=116\left(\mathrm{Y} / \mathrm{Y}_{0}\right)^{1 / 3}-16 \\
& \mathrm{a}^{*}=500\left[\left(\mathrm{X} / \mathrm{X}_{0}\right)^{1 / 3}-\left(\mathrm{Y} / \mathrm{Y}_{0}\right)^{1 / 3}\right] \\
& \mathrm{b}^{*}=200\left[\left(\mathrm{Y} / \mathrm{Y}_{0}\right)^{1 / 3}-\left(\mathrm{Z} / \mathrm{Z}_{0}\right)^{1 / 3}\right]
\end{aligned}
$$

where, $\mathrm{X}_{0}, \mathrm{Y}_{0}, \mathrm{Z}_{0}$ are the tristimulus values of specified achromatic light used for illuminating the untreated color fabrics, while $X, Y, Z$ are the values for the colored fabrics, respectively. The value of $Y_{0}$ has been normalized in such a way that $Y_{0}=100$. The color characteristics of the dyed cotton fabric treated with dendrimers are summarised in Table 1 . The results show that, the dyed cotton fabrics have a yellow color. In the case of using metallodendrimer $\left[\mathrm{Cu}_{2}(\mathrm{D})\left(\mathrm{NO}_{3}\right)_{4}\right]$, the cotton fabric obtains a yellow color deeper than the one of the cotton fabric treated with $\mathrm{D}$. The color difference $\Delta \mathrm{E} *$ has been calculated according to equation 4 . These values have been used for the quantitative determination of color [31].

$$
\Delta \mathrm{E} *=\left[(\Delta \mathrm{L} *)^{2}+(\Delta \mathrm{a} *)^{2}+(\Delta \mathrm{b} *)^{2}\right]^{1 / 2}
$$

, where $\Delta \mathrm{L} *, \Delta \mathrm{a} *, \Delta \mathrm{b}^{*}$ are the difference in the coordinates of the control cotton fabric and of respective cotton fabrics treated with dendrimer $\mathrm{D}$ and $\left[\mathrm{Cu}_{2}(\mathrm{D})\left(\mathrm{NO}_{3}\right)_{4}\right]$, respectively. The value of the untreated cotton fabric is $\Delta \mathrm{E} *=0$. The results show that, when loading the fabric with the metallodendrimer, the color saturation achieved $(\Delta \mathrm{E} *=39.247)$ is better than the yielding when dendrimer $\mathrm{D}(\Delta \mathrm{E} *=34.791)$ is used.

Table 1. Color characteristics of treated with dendrimers $\mathrm{D}$ and $\left[\mathrm{Cu}_{2}(\mathrm{D})\left(\mathrm{NO}_{3}\right)_{4}\right]$ cotton fabric.

\begin{tabular}{l|l|l|l|l|l|l|l|l} 
Cotton samples & $\mathbf{L}^{*}$ & $\mathbf{a}^{*}$ & $\mathbf{b}^{*}$ & $\mathbf{X}$ & $\mathbf{Y}$ & $\mathbf{Z}$ & $\mathbf{x}$ & $\mathbf{y}$ \\
\hline Cotton & 93.77 & -0.26 & 3.75 & 80.22 & 84.75 & 85.65 & 0.3201 & 0.3382 \\
\hline Cotton $+\mathrm{D}$ & 92.81 & -7.44 & 37.78 & 74.58 & 82.45 & 45.11 & 0.3688 & 0.4081 \\
\hline Cotton $+\left[\mathrm{Cu}_{2}(\mathrm{D})\left(\mathrm{NO}_{3}\right)_{4}\right]$ & 95.82 & -11.39 & 41.33 & 79.00 & 89.53 & 46.58 & 0.3673 & 0.4162
\end{tabular}

\subsection{Biological investigations.}

\subsubsection{Antimicrobial activity.}

The effect of light on the antimicrobial activity of the investigated $\left[\mathrm{Cu}_{2}(\mathrm{D})\left(\mathrm{NO}_{3}\right)_{4}\right]$ against Gram-negative bacteria $P$. aeruginosa has been tested by the broth dilution test. The experiments were conducted in a planktonic format in solution and applied on cotton fabric. The microbial growth decreases with the increasing concentration of $\left[\mathrm{Cu}_{2}(\mathrm{D})\left(\mathrm{NO}_{3}\right)_{4}\right]$ in the presence of light and the dark. Under light irradiation, it is lower than in the dark, which indicates higher antimicrobial activity (Figure 3). The higher antimicrobial activity of the studied photoactive dendrimer under light irradiation can be explained by its ability to bind to the bacterial membrane and generate reactive oxygen upon photostimulation [32]. 


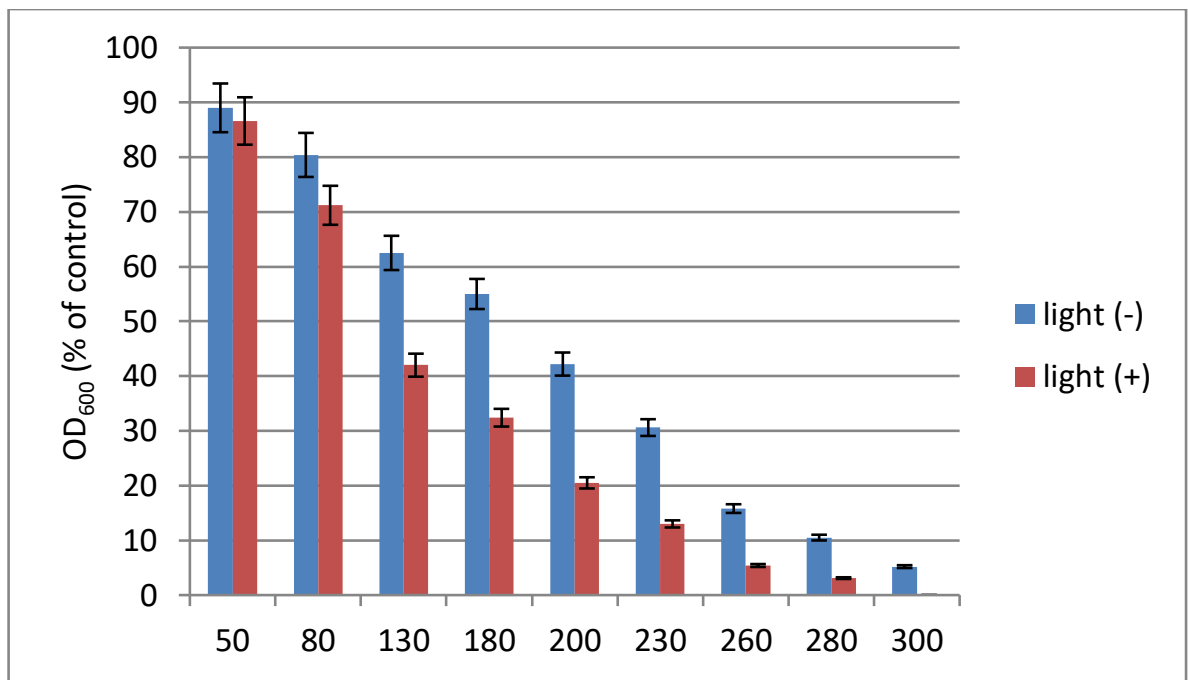

Figure 3. Growth (expressed by $\mathrm{OD}_{600}$ ) of $P$. aeruginosa at different concentrations of $\left[\mathrm{Cu}_{2}(\mathrm{D})\left(\mathrm{NO}_{3}\right)_{4}\right]$ under light irradiation and in the dark.

\subsubsection{Antimicrobial activity of modified cotton fabric.}

The antimicrobial effect of the cotton fabric treated with $\left[\mathrm{Cu}_{2}(\mathrm{D})\left(\mathrm{NO}_{3}\right)_{4}\right]$ has been tested in nutrient broth by reducing the growth of $P$. aeruginosa as a model strain. The results reveal that the presence of light cotton fabric treated with $\left[\mathrm{Cu}_{2}(\mathrm{D})\left(\mathrm{NO}_{3}\right)_{4}\right]$ inhibits microbial growth by about $22 \%$ and by about $14 \%$ in the dark. Mettalodendrimer $\left[\mathrm{Cu}_{2}(\mathrm{D})\left(\mathrm{NO}_{3}\right)_{4}\right]$ is being attached to the cotton surface mainly by hydrogen bonds and Van der Waals interactions. It is hypothesized that the direct contact of bacterial cells with cotton surfaces contributes to the antimicrobial effect of the treated cotton fabric. The low water solubility of $\left[\mathrm{Cu}_{2}(\mathrm{D})\left(\mathrm{NO}_{3}\right)_{4}\right]$ does not allow the easy release of bacterial cells from the cotton surface to contact directly with bacterial cells in solution. That explains the low growth inhibition of the tested bacteria in the solution.

\subsubsection{Hydrophilicity of cotton fabrics.}

The hydrophilicity of cotton fabric specimens has been measured by a static immersion test. The results showed water absorption of the cotton sample treated with $\left[\mathrm{Cu}_{2}(\mathrm{D})\left(\mathrm{NO}_{3}\right)_{4}\right]$ $(86 \% \pm 1.4)$ to be lower than that of the untreated sample $(115 \% \pm 3.2)$. That suggests that, when applied onto cotton fabric, the studied dendrimer gains hydrophobic properties, which contribute to the antimicrobial effect of the treated cotton fabric.

3.5. Studies on the behavior of potassium iodide in the presence of $\left[\mathrm{Cu}_{2}(\mathrm{D})\left(\mathrm{NO}_{3}\right)_{4}\right]$ and while being deposited on the cotton fabric.

The iodometric method has been used for the production of singlet oxygen $\left({ }^{1} \mathrm{O}_{2}\right)$ after the irradiation of $\left[\mathrm{Cu}_{2}(\mathrm{D})\left(\mathrm{NO}_{3}\right)_{4}\right]$ solutions at a concentration of $1 \times 10^{-7} \mathrm{M}$, as well as from the cotton fabrics dyed with $\left[\mathrm{Cu}_{2}(\mathrm{D})\left(\mathrm{NO}_{3}\right)_{4}\right]$ [33-35]. This method is based on the reaction of the singlet oxygen released when irradiating the dendrimers with $\mathrm{I}^{-}$to give $\mathrm{I}_{3}^{-}$by the following mechanism.

$$
\begin{array}{ll}
{\left[\mathrm{Cu}_{2}(\mathrm{D})\left(\mathrm{NO}_{3}\right)_{4}\right] \mathrm{o}+\mathrm{h} v \rightarrow{ }^{1}\left[\mathrm{Cu}_{2}(\mathrm{D})\left(\mathrm{NO}_{3}\right)_{4}\right]} & \text { light excitation } \\
{ }^{1}\left[\mathrm{Cu}_{2}(\mathrm{D})\left(\mathrm{NO}_{3}\right)_{4}\right] \rightarrow{ }^{3}\left[\mathrm{Cu}_{2}(\mathrm{D})\left(\mathrm{NO}_{3}\right)_{4}\right] & \text { intersystem crossing } \\
{ }^{3}\left[\mathrm{Cu}_{2}(\mathrm{D})\left(\mathrm{NO}_{3}\right)_{4}\right]+{ }^{3} \mathrm{O}_{2} \rightarrow\left[\mathrm{Cu}_{2}(\mathrm{D})\left(\mathrm{NO}_{3}\right)_{4}\right] \mathrm{o}+{ }^{1} \mathrm{O}_{2} & \text { transfer oy energy } \\
{ }^{1} \mathrm{O}_{2}+\mathrm{I}^{-} \rightarrow \mathrm{IOO}^{-} \rightarrow \mathrm{IOOH} &
\end{array}
$$


$\mathrm{IOOH}+\mathrm{I}^{-} \rightarrow \mathrm{HOOI}_{2}^{-} \rightarrow \mathrm{I}_{2}+\mathrm{HO}_{2}^{-} \rightarrow \mathrm{I}_{3}^{-}+\mathrm{H}_{2} \mathrm{O}_{2}+\mathrm{OH}^{-}$

where: $\left[\mathrm{Cu}_{2}(\mathrm{D})\left(\mathrm{NO}_{3}\right)_{4}\right] \mathrm{o},{ }^{1}\left[\mathrm{Cu}_{2}(\mathrm{D})\left(\mathrm{NO}_{3}\right)_{4}\right]$ and ${ }^{3}\left[\mathrm{Cu}_{2}(\mathrm{D})\left(\mathrm{NO}_{3}\right)_{4}\right]$ are the metallodendrimer (used as PS) in the ground, singlet and in the triplet excited state.

$\mathrm{KI}(5 \mathrm{ml} \quad 0.5 \mathrm{M})$ solution containing metallodendrimer $\left[\mathrm{Cu}_{2}(\mathrm{D})\left(\mathrm{NO}_{3}\right)_{4}\right]$ at a concentration of 1x10-7 M has been irradiated by a Newport solar simulator: $185-1100 \mathrm{~nm}$, Xe lamp $150 \mathrm{~W}$, at $30 \mathrm{~cm}$ sample distance. The absorption spectra of the solution have been recorded in the $250 \div 500 \mathrm{~nm}$ spectral range at intervals of 5 minutes. The spectra of photooxidation of $\mathrm{I}^{-}$to $\mathrm{I}^{3-}$, which is caused by the release of singlet oxygen during the irradiation of metallodendrimer $\left[\mathrm{Cu}_{2}(\mathrm{D})\left(\mathrm{NO}_{3}\right)_{4}\right]$ are plotted in Figure 4. Two well-pronounced maxima at 288 and $352 \mathrm{~nm}$ have been registered in the studied spectral region, which is characteristic for $\mathrm{I}^{3-}$ formed in the solution (Figure 4A). The absorption increases depending on the irradiation time, which can be explained by the increment of the quantity of the singlet oxygen. The same results have been obtained when using cotton fabric treated with $\left[\mathrm{Cu}_{2}(\mathrm{D})\left(\mathrm{NO}_{3}\right)_{4}\right]$ (Figure 4B). That indicates that the metallodendrimer deposited onto the cotton fabric retains its activity to generate singlet oxygen during the irradiation. Figure $4 \mathrm{C}$ compares the absorbance dependence at $352 \mathrm{~nm}$ as a function of the irradiation time of $\left[\mathrm{Cu}_{2}(\mathrm{D})\left(\mathrm{NO}_{3}\right)_{4}\right]$ in solution and after its deposition onto the cotton fabric. As seen, the activity of the dendrimer increases. The irradiated solutions of $\left[\mathrm{Cu}_{2}(\mathrm{D})\left(\mathrm{NO}_{3}\right)_{4}\right]$ and of cotton dyed fabric without KI have been used as control. No absorption of the solutions has been registered, which evidences the lack of singlet oxygen.
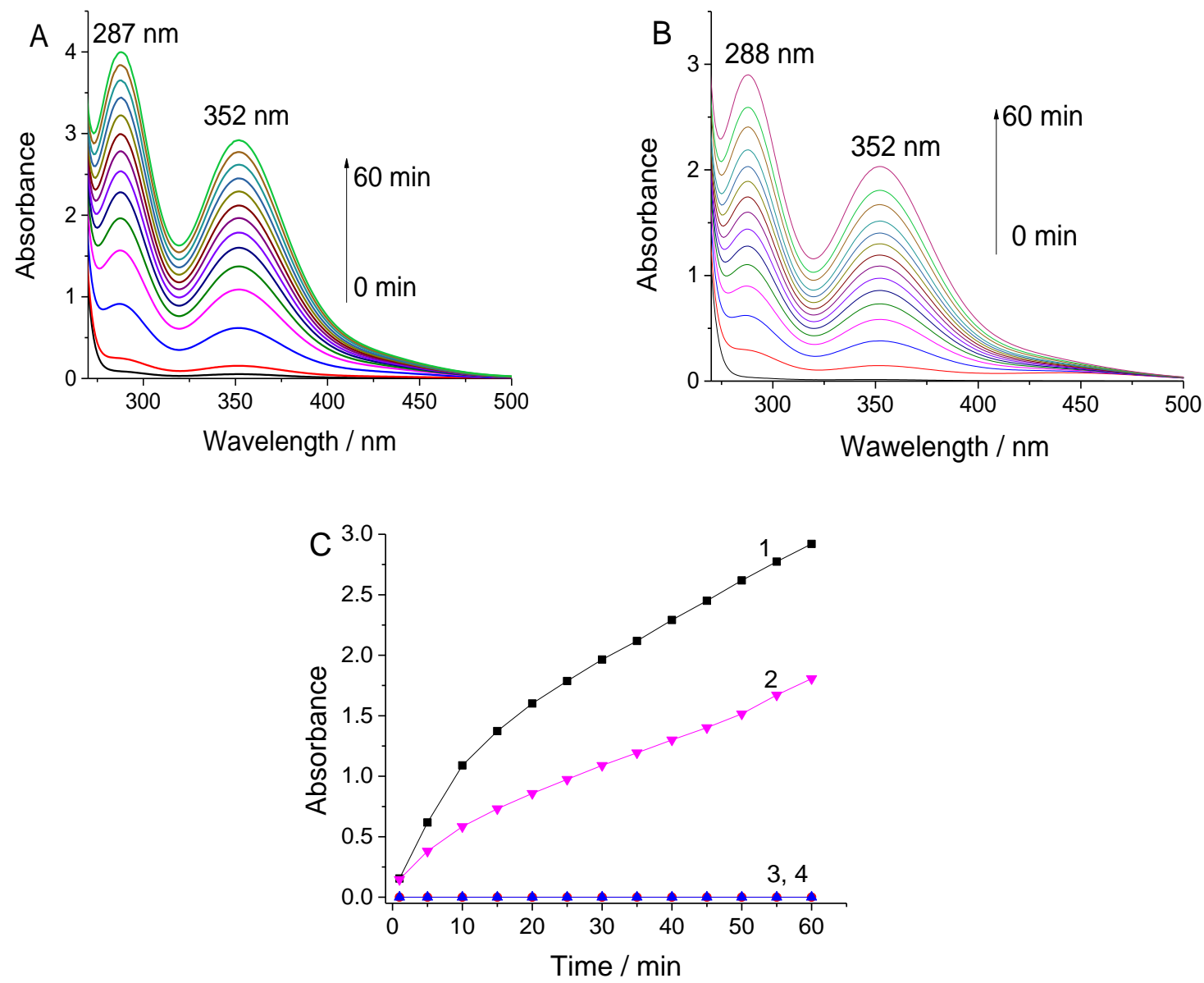

Figure 4. Absorption spectra of $\mathrm{KI}(0.5 \mathrm{M})$ photoxidated to $\mathrm{I}_{3}{ }^{-}$as a function of the irradiation time: $(\mathbf{A})$ in the presence of a $1 \mathrm{~cm}^{2}$ cotton fabric dyed with $\left[\mathrm{Cu}_{2}(\mathrm{D})\left(\mathrm{NO}_{3}\right)_{4}\right]$ and $(\mathbf{B})$ in a solution of $\left[\mathrm{Cu}_{2}(\mathrm{D})\left(\mathrm{NO}_{3}\right)_{4}\right] ;(\mathbf{C})$ Dependence of absorbance at $352 \mathrm{~nm}$, corresponding to $\mathrm{I}_{3}{ }^{-}$caused by: (1) cotton fabric dayed $\left[\mathrm{Cu}_{2}(\mathrm{D})\left(\mathrm{NO}_{3}\right)_{4}\right]$,

(2) solution of $\left[\mathrm{Cu}_{2}(\mathrm{D})\left(\mathrm{NO}_{3}\right)_{4}\right]$ comprising: (3) only the dendrimer and (4) only dyed cotton fabrics. 
3.6. Cytotoxic activity.

\subsubsection{Short-term experiments.}

The cytotoxic activity of $\left[\mathrm{Cu}_{2}(\mathrm{D})\left(\mathrm{NO}_{3}\right)_{4}\right]$ and its ligand $\mathrm{D}$ has been examined against the human triple-negative breast cancer cells (permanent cell line MDA-MB-231) after $24 \mathrm{~h}$ and $48 \mathrm{~h}$ treatment periods. The research has been initiated by an MTT test - the gold standard for cytotoxicity assays. The viability of MDA-MB-23 cells has been monitored at different concentrations of the dendrimers in the $16-133 \mu \mathrm{M}$ range. The results obtained are plotted in Figure 5A, which shows that metallodendrinmer $\left[\mathrm{Cu}_{2}(\mathrm{D})\left(\mathrm{NO}_{3}\right)_{4}\right]$ has a more pronounced cytotoxic activity compared to that of its ligand. The percent of viable cells has been decreased to $42.2 \%\left(\left[\mathrm{Cu}_{2}(\mathrm{D})\left(\mathrm{NO}_{3}\right)_{4}\right]\right)$ and $48.0 \%$ (D) for the first $24 \mathrm{~h}$, as compared to the one caused by the control (Figure 5A). In the next $24 \mathrm{~h}$, the reduction in tumor cells was significant, and around $0.5-1.0 \%$ viable cells were found after cultivation in the presence of the compounds examined, which had been administered at a concentration of $133 \mu \mathrm{M}$ - relative to the tumor cells untreated with the dendrimers (Figure 5B).
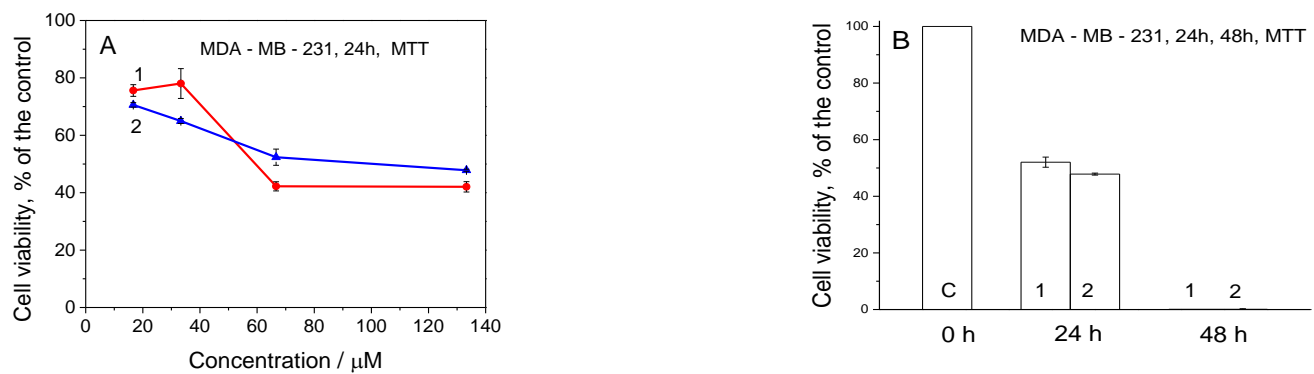

Figure 5. (A) Effect of concentration of dendrimer D (1) and $\left[\mathrm{Cu}_{2}(\mathrm{D})\left(\mathrm{NO}_{3}\right)_{4}\right]$ (2) on cell viability of MDA-MB231 human breast cancer cells for $24 \mathrm{~h}$. (B) Cell viability at a concentration of both dendrimers $133 \mu \mathrm{M}$ for $24 \mathrm{~h}$ and for $48 \mathrm{~h}$.

The cytopathological changes in MDA-MB-231 cells induced by dendrimer D and $\left[\mathrm{Cu} 2(\mathrm{D})\left(\mathrm{NO}_{3}\right)_{4}\right]$ at concentrations of $16 \mu \mathrm{M}$ and $66 \mu \mathrm{M}$ for $48 \mathrm{~h}$ at double staining with acridine orange and propidium iodide have been investigated by fluorescence microscopy, and the results are shown in Figure 6.
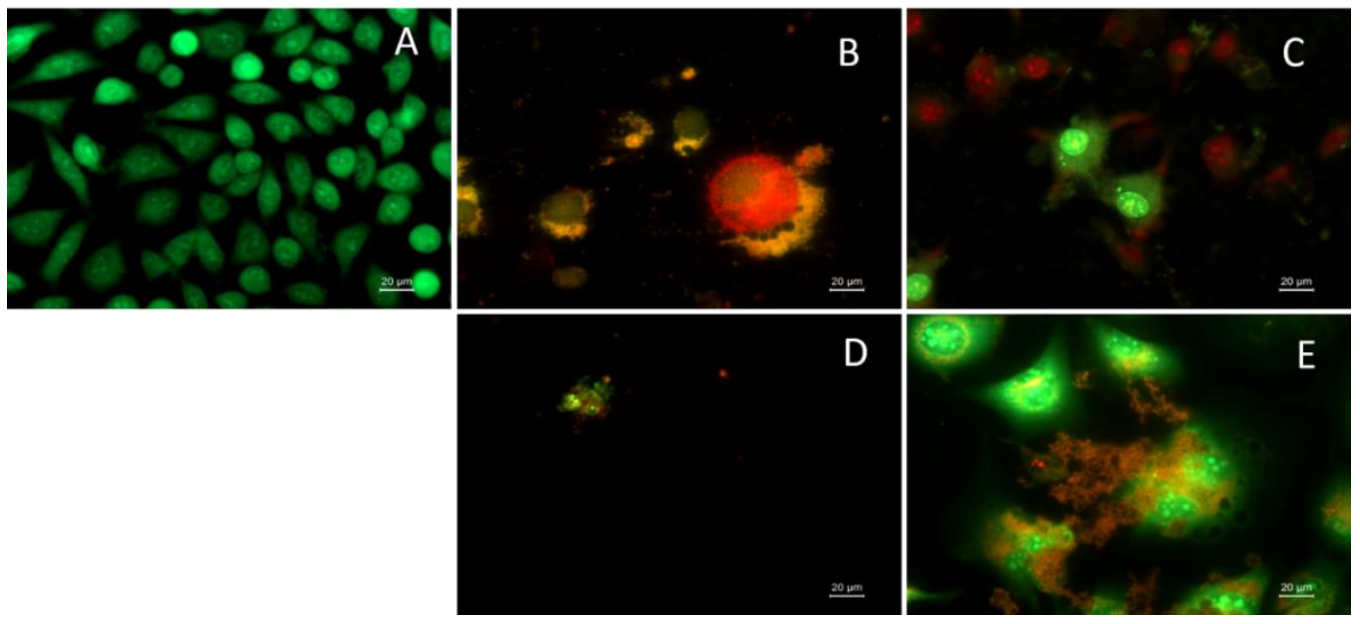

Figure 6. Human triple-negative breast cancer cells (MDA-MB-231 cell line) - (A) culture medium control; (B) culture medium treated for $48 \mathrm{~h}$ with $16 \mu \mathrm{M}$ of $\left[\mathrm{Cu}_{2}(\mathrm{D})\left(\mathrm{NO}_{3}\right)_{4}\right] ;(\mathbf{C})$ culture medium treated for $48 \mathrm{~h}$ with 16 $\mu \mathrm{M}$ of dendrimer $\mathrm{D}$; (D) culture medium treated for $48 \mathrm{~h}$ with $66 \mu \mathrm{M}$ of $\left[\mathrm{Cu}_{2}(\mathrm{D})\left(\mathrm{NO}_{3}\right)_{4}\right]$; (E) culture medium treated for $48 \mathrm{~h}$ with $66 \mu \mathrm{M}$ of dendrimer D. Double staining with acridine orange and propidium iodide. (Leica DM 5000B, Leica Microsystems, Germany, 40x). Bar $=20 \mu \mathrm{m}$. 
A monolayer of vital untreated cells from the MDA-MB-231 line with pale green nuclear fluorescence and bright yellow-green nuclei was used as a control (6A). After $24 \mathrm{~h}$ of culturing the cells in the presence of $16 \mu \mathrm{M}\left[\mathrm{Cu} 2(\mathrm{D})\left(\mathrm{NO}_{3}\right)_{4}\right]$, enlarged dead cells with bright red nuclei of orange color and red fluorescence were observed (6B). During the treatment with dendrimer D, a significant decrease of vital cells was observed simultaneously, with many reduced dead cells stained in orange-red color (6C). With increasing concentration of metallodendrimer $(66 \mu \mathrm{M})$, single reduced dead cells (6D) were observed, while when treated with dendrimer $\mathrm{D}$, enlarged and rounded fused cells with a large number of red and bright green lysosomal granules were observed $(6 \mathrm{E})$.

\subsubsection{Long-term experiments.}

The effect that the tested dendrimers $\mathrm{D}$ and [Cu2(D)(NO3)4] have on the anchorageindependent growth of MDA-MB-231 cells has also been evaluated after a 10 day incubation period. The results show that $\left[\mathrm{Cu}_{2}(\mathrm{D})\left(\mathrm{NO}_{3}\right)_{4}\right]$ completely inhibits $3 \mathrm{D}$ growth of human tumor cells at $\geq 33 \mu \mathrm{M}$, while D1 at a concentration of $\geq 66 \mu \mathrm{M}$ reduces the tumor formation.

Table 2. Effect of the dendrimers on the colony-forming ability of human triple-negative breast cancer cells (MDA-MB-231 cell line).

\begin{tabular}{l|l|l} 
Compound & Concentration, $\boldsymbol{\mu M}$ & Colony formation, $\mathbf{1 0}^{\text {th }}$ day \\
\hline Control & & $\begin{array}{l}\text { Large colonies } \\
>10 \text { on visual field }\end{array}$ \\
\hline$\left[\mathrm{Cu}_{2}(\mathrm{D})\left(\mathrm{NO}_{3}\right)_{4}\right]$ & 16 & Up to 10 colonies per visual field \\
\cline { 2 - 3 } & $33,66,133$ & Single cells \\
\hline $\mathrm{D}$ & 16 & $\begin{array}{l}\text { No inhibition } \\
(>10 \text { on visual field })\end{array}$ \\
\cline { 2 - 3 } & 33,66 & Up to 10 colonies per visual field \\
\cline { 2 - 3 } & 133 & Up to 5 colonies per visual field
\end{tabular}

\section{Conclusions}

A new metallodendrimer $\left[\mathrm{Cu}_{2}(\mathrm{D})\left(\mathrm{NO}_{3}\right)_{4}\right]$ based on a PAMAM dendrimer of zero generation modified with 1,8-naphthalimide has been designed, synthesized, and characterized. The new compound underwent studies by IR and EPR spectroscopy for selecting the optimal conditions for its deposition onto cotton fabric. The color characteristics of the dyed textile materials obtained have been determined. Antimicrobial activity of the new metallodendrimer has been studied against Gram-negative bacterium $P$. aeroginosa in the dark and after irradiation with visible light. It has been found that upon irradiation with visible light, the metallodendrimer exhibits more antimicrobial activity than in the dark due to the generation of reactive singlet oxygen. That is an indication that the metallodendrimer investigated has the potential to be used in the design of formulations with antibacterial photodynamic activity. Antitumor activity of the metallodendrimer $\left[\mathrm{Cu}_{2}(\mathrm{D})\left(\mathrm{NO}_{3}\right)_{4}\right]$ and its ligand $\mathrm{D}$ have also been evaluated against human triple-negative breast cancer cells (MDA-MB-231 cell line). The results have revealed that the metallodendrimer possesses an antitumor activity higher than that exhibited by dendrimer $\mathrm{D}$.

\section{Funding}

This research received no external funding. 


\section{Acknowledgments}

The authors acknowledge Grant № KП-06-KOCT/ 4, Fund "Scientific Research", Ministry of Education and Science of Bulgaria.

\section{Conflicts of Interest}

The authors declare no conflict of interest.

\section{References}

1. Pooresmaeila, M.; Namaz H. Advances in development of the dendrimers having natural saccharides in their structure for efficient and controlled drug delivery applications, European Polymer Journal 2021, 148, 110356, https://doi.org/10.1016/j.eurpolymj.2021.110356.

2. Filipczak, N.; Yalamarty, S.S.K.; Li, X.; Parveen, F.; Torchilin, V. Developments in Treatment Methodologies Using Dendrimers for Infectious Diseases. Molecules 2021, 26, 3304, https://doi.org/10.3390/molecules26113304.

3. Mlynarczyk, D.T.; Dlugaszewska, J.; Kaluzna-Mlynarczyk, A.; Goslinski, T. Dendrimers against fungi - A state of the art review. J. Control Release 2021, 330, 599-617, https://doi.org/10.1016/j.jconrel.2020.12.021.

4. Tarach, P.; Janaszewska, A. Recent Advances in Preclinical Research Using PAMAM Dendrimers for Cancer Gene Therapy. Int. J. Mol. Sci. 2021, 22, 2912, https://doi.org/10.3390/ijms22062912.

5. Staneva, D.; Vasileva-Tonkova, E.; Yordanova, S.; Kukeva, R.; Stoyanova, Grabchev , I. Spectral characterization, antimicrobial and antibiofilm activity of poly (propylene imine) metallodendrimers in solution and applied onto cotton fabric, Int. J. Polym. Anal. Charact. 2020, 25, 374-384, https://doi.org/10.1080/1023666X.2020.1796105.

6. Sanz del Olmo, N.; Carloni, R.; Ortega, P.; García-Gallego, S.; Javier de la Mata, F. Metallodendrimers as a promising tool in the biomedical field: An overview. Adv. Organomet. Chem. 2020, 74, 1-52, https://doi.org/10.1016/bs.adomc.2020.03.001.

7. Mignani, S.; Bignon, J.; Shi, X.; Majoral, J.-P. First-in-Class Phosphorus Dendritic Framework, a Wide Surface Functional Group Palette Bringing Noteworthy Anti-Cancer and Anti-Tuberculosis Activities: What Lessons to Learn? Molecules 2021, 26, 3708, https://doi.org/10.3390/molecules26123708.

8. Alami, O.; Laurent, R.; Majoral, J.-P.; El Brahmi, N.; El Kazzouli, S.; Caminade, A.-M. Copper complexes of phosphorus dendrimers and their properties. Inorg. Chim. Acta 2021, 517, 120212, https://doi.org/10.1016/j.ica.2020.120212.

9. Carloni, R.; Sanz Del Olmo, N.; Canonico, B.; Montanari, M.; Ciacci, C.; Ambrosi, G.; Javier de la Mata, F.; Ottaviani, M.F.; García-Gallego, S. Elaborated study of $\mathrm{Cu}$ (II) carbosilane metallodendrimers bearing substituted iminopyridine moieties as antitumor agents. Eur. J. Med. Chem. 2021, 215, 11392, https://doi.org/10.1016/j.ejmech.2021.113292.

10. Sanz del Olmo, N.; Holota, M.; Michlewska, S.; Gómez, R.; Ortega, P.; Ionov, M.; de la Mata, F.J.; Bryszewska, M. Copper (II) Metallodendrimers Combined with Pro-Apoptotic siRNAs as a Promising Strategy Against Breast Cancer Cells. Pharmaceutics 2020, 12, 727, https://doi.org/10.3390/pharmaceutics12080727.

11. Grabchev, I.; Staneva, D.; Betcheva, R. Fluorescent dendrimers as sensors for biologically important metal cation. Curr. Med. Chem. 2012, 29, 4976-4983, https://doi.org/10.2174/0929867311209024976.

12. Staneva, D.; Grabchev, I. Chapter 20 - Dendrimer as antimicrobial agents. Dendrimer-Based Nanotherapeutics 2021, 363-384, https://doi.org/10.1016/B978-0-12-821250-9.00016-0.

13. Tutov, M.V.; Sergeev, A.A.; Shamich, N.I.; Chepak, A.K.; Mironenko, Yu.A. Synthesis and optical properties of rhodamine terminated organosilicon dendrimers. Dyes Pigm. 2021, 184, 108783, https://doi.org/10.1016/j.dyepig.2020.108783.

14. Staneva, D.; Grabchev, I. Heterogeneous sensors for ammonia, amines and metal ions based on a dendrimer modified fluorescent viscose fabric. Dyes Pigm. 2018, 155, 164-170, https://doi.org/10.1016/j.dyepig.2018.03.044.

15. Bosch P.; Staneva, D.; Vasileva-Tonkova, E.; Grozdanov, P.; Nikolova, I.; R. Kukeva, R.; Stoyanova, R.; Grabchev, I. New Poly (Propylene Imine) Dendrimer Modified with Acridine and Its Cu (II) Complex: Synthesis, Characterization and Antimicrobial Activity. Materials 2019, 12, 3020, https://doi.org/10.3390/ma12183020.

16. Staneva, D.; Yordanova, S.; Vasileva-Tonkova, E.; Stoyanov, S.; Grabchev, I. Synthesis of a new fluorescent poly (propylene imine) dendrimer modified with 4-nitrobenzofurazan. Sensor and antimicrobial activity. $J$. Photochem. Photobiol. A Chemistry 2020, 395, 112506, https://doi.org/10.1016/j.jphotochem.2020.112506. 
17. Dodangeh, M.; Gharanjig, K.; Tang, R.C.; Grabchev, I. Functionalization of PAMAM dendrimers with curcumin: Synthesis, characterization, fluorescent improvement and application on PET polymer. Dyes Pigm. 2020, 174, 108081, https://doi.org/10.1016/j.dyepig.2019.108081.

18. Staneva, D.; Vasileva-Tonkova, E.; Bosch, P.; Grozdanov, P.; Grabchev, I. Synthesis and characterization of a new PAMAM metallodendrimer for antimicrobial modification of cotton fabric. Macromol. Res. 2018, 26, 332, https://doi.org/10.1007/s13233-018-6043-X.

19. Grabchev, I.; Vasileva-Tonkova, E.; Staneva, D.; Bosch, P.; Kukeva, R.; Stoyanova, R. Impact of Cu (II) and $\mathrm{Zn}$ (II) ions on the functional properties of new PAMAM metallodendrimers. New J. Chem. 2018, 42, 78537862, https://doi.org/10.1039/C8NJ00384J.

20. Staneva, D.; Vasileva-Tonkova, E.; Grabchev, I. pH sensor potential and antimicrobial activity of a new PPA dendrimer modified with benzanthrone fluorophores in solution and on viscose fabric. J. Photochem. Photobiol. A Chemistry 2019, 375, 24-29, https://doi.org/10.1016/j.jphotochem.2019.02.004.

21. Grabchev, I.; Vasileva-Tonkova, E.; Staneva, D.; Bosch, P.; Kukeva, R.; Stoyanova, R. Synthesis, spectral characterization, and in vitro antimicrobial activity in liquid medium and applied on cotton fabric of a new PAMAM metallodendrimer. Int. J. Polym. Anal. Charact. 2018, 23, 45-57, https://doi.org/10.1080/1023666X.2017.1387025.

22. Grabchev, I.; Staneva, D.; Vasileva-Tonkova, E.; Alexandrova, R. Surface Functionalization of Cotton Fabric with Fluorescent Dendrimers, Spectral Characterization, Cytotoxicity, Antimicrobial and Antitumor Activity. Chemosensors 2019, 7, 17, https://doi.org/10.3390/chemosensors7020017.

23. Ingrassia, L.; LeFranc, F.; Kiss, R.; Mijatovic, T. Naphthalimides and Azonafides as Promising Anti-Cancer Agents. Curr. Med. Chem. 2009, 16, 1192-1213, https://doi.org/10.2174/092986709787846659.

24. Gong, H.H.; Addla, D.; Lv, J.S.; Zhou, C.H. Heterocyclic naphthalimides as new skeleton structure of compounds with increasingly expanding relational medicinal applications. Curr. Top. Med. Chem. 2016, 16, 3303-3364, https://doi.org/10.2174/1568026616666160506145943.

25. Carretero, G.P.B.; Saraiva, G.K.V.; Rodrigues, M.A.; Kiyota, S.; Bemquerer, M.P.; Chaimovich, H.; Cuccovia, I.M. Naphthalimide-Containing BP100 Leads to Higher Model Membranes Interactions and Antimicrobial Activity. Biomolecules 2021, 11, 542, https://doi.org/10.3390/biom11040542.

26. Rykowski, S.; Gurda-Woźna, D.; Orlicka-Płocka, M.; Fedoruk-Wyszomirska, A.; Giel-Pietraszuk, M.; Wyszko, E.; Kowalczyk, A.; Stączek, P.; Bak, A.; Kiliszek, A.; Rypniewski, W.; Olejniczak, A.B. Design, Synthesis, and Evaluation of Novel 3-Carboranyl-1,8-Naphthalimide Derivatives as Potential Anticancer Agents. Int. J. Mol. Sci. 2021, 22, 2772, https://doi.org/10.3390/ijms22052772.

27. Grabchev, I.; Qian, X.; Bojinov, V.; Xiao, Y.; Zhang, W. Synthesis and Photophysical Properties of 1,8Naphthalimide Labelled Dendrimers as PET Sensors of Proton and Transition Metal Ion. Polymer 2002, 43, 5731-5736, https://doi.org/10.1016/S0032-3861(02)00417-2.

28. Grabchev, I.; Chovelon, J.-M.; Qian, X. Polyamidoamine Dendrimer with Peripheral 1,8-naphthalimide Groups Capable of Acting as PET Fluorescent Sensor for Metal Cations. New J. Chem. 2003, 27, 337-340, https://doi.org/10.1039/B204727F.

29. Panchenko, P.A.; Fedorova, O.A.; Fedorov, Yu.V. Fluorescent and colorimetric chemosensors for cations based on 1,8-naphthalimide derivatives: design principles and optical signalling mechanisms. Russ. Chem. Rev. 2014, 83, 155-182, http://dx.doi.org/10.1070/RC2014v083n02ABEH004380.

30. Peisach, J.; Blumberg, W.E. Structural implications derived from the analysis of electron paramagnetic resonance spectra of natural and artificial copper proteins. Arch. Biochem. Biophys. 1974, 165, 691-708, https://doi.org/10.1016/0003-9861(74)90298-7.

31. Becerir, B. A novel approach for estimating the relation betweenK/S value and dye uptake in reactive dyeing of cotton fabrics. Fibers and Polymers 2005, 6, 224-228, https://doi.org/10.1007/BF02875646.

32. Sperandio, F.F.; Huang, Y.-Y.; Hamblin, M.R. Antimicrobial Photodynamic Therapy to Kill Gram-negative Bacteria. Recent Pat. Antiinfect. Drug Discov. 2013, 8, 108-120, https://doi.org/10.2174/1574891x113089990012.

33. López-Fernández, A.M.; Muñoz Resta, I.; de Llanos, R.; Galindo, F. Photodynamic Inactivation of Pseudomonas aeruginosa by PHEMA Films Loaded with Rose Bengal: Potentiation Effect of Potassium Iodide. Polymers 2021, 13, 2227, https://doi.org/10.3390/polym13142227.

34. Wan, L.; Yiming, X. Iodine-sensitized oxidation of ferrous ions under UV and visible light: the influencing factors and reaction mechanism. Photochem. Photobiol. Sci. 2013, 12, 2084-2089, https://doi.org/10.1039/C3PP50245G.

35. Bartolomeu, M.; Oliveira, C.; Pereira, C.; Neves, M.G.P.M.S.; Faustino, M.A.F.; Almeida, A. Antimicrobial Photodynamic Approach in the Inactivation of Viruses in Wastewater: Influence of Alternative Adjuvants. Antibiotics 2021, 10, 767, https://doi.org/10.3390/antibiotics10070767. 


\section{Supporting Information}

\section{Spectral measurements}

Varian Cary 5000 UV-Vis-NIR Spectrophotometer has been used for UV-vis spectrophotometric measurements. The color coordinates $\left(\mathrm{L}^{*} \mathrm{a}^{*} \mathrm{~b}^{*}, \mathrm{XYZ}\right.$ and $\mathrm{xy}$ ) of dyed cotton fabric with dendrimers were determined by Datacolor Spectraflash SF300 spectrophotometer (Datacolor, NJ, USA) and Micromatch 2000® software. Dulbecco's modified Eagle's medium (DMEM) and fetal bovine serum (FBS) were purchased from GibcoInvitrogen (UK). Dimethyl sulfoxide (DMSO), neutral red, crystal violet, and trypsin were obtained from AppliChem (Germany), thiazolyl blue tetrazolium bromide (MTT), trypan blue and purified agarose were from Sigma-Aldrich Chemie GmbH (Germany). The antibiotics (penicillin and streptomycin) were from Lonza (Belgium).

\section{Antimicrobial assay}

The ability of the compound $\left[\mathrm{Cu}_{2}(\mathrm{D})\left(\mathrm{NO}_{3}\right)_{4}\right]$ to inhibit the growth of Gram-negative strain Pseudomonas aeruginosa was tested in meat-peptone broth (MPB) in the presence of light and in the dark. The compound was dissolved in DMSO at a starting concentration of 5 $\mathrm{mg} / \mathrm{mL}$ and further diluted serially in test tubes with meat-peptone broth (MPB) to final concentrations in the range of 51-306 $\mu \mathrm{M}$. Two sets of tubes were prepared - for experiments in the presence of light and in the dark. After inoculation with standardized cell suspension, the tubes were incubated at an appropriate temperature for $20 \mathrm{~h}$ under shaking. Positive controls (compound and MPB, without inoculum) and negative controls (MPB and inoculum, without compounds) were used. The turbidity of the medium at $600 \mathrm{~nm}\left(\mathrm{OD}_{600}\right)$ was determined as a measure of microbial growth. The lowest concentration of dendrimers that inhibited the growth of the strain by more than $90 \%$ was referred to as MIC. The experiments were conducted in triplicate, and the averages were taken (standard deviations less than 5\%). The antibacterial effect of cotton fabric treated with $0.25 \mathrm{w} \%$ solution of $\left[\mathrm{Cu}_{2}(\mathrm{D})\left(\mathrm{NO}_{3}\right)_{4}\right]$ was tested against $P$. aeruginosa in MPB under light irradiation and in the dark. Test tubes containing MPB and square-shaped cotton specimens $(10 \mathrm{~mm} \times 10 \mathrm{~mm})$ were inoculated with standardized microbial suspension. Tubes with native cotton and without specimens were also prepared as controls. Two sets of tubes were prepared for testing in the presence and absence of light. After $20 \mathrm{~h}$ incubation at an appropriate temperature, the specimens were removed, and OD600 determined microbial growth. The antimicrobial activity of the samples was evaluated by the reduction of bacterial growth in the presence of the treated specimens compared to native. All assays were performed in triplicate, and the averages were taken (standard deviations less than $5 \%)$.

\section{Assessment of hydrophilicity of cotton fabrics}

The hydrophilicity of the untreated cotton fabric and cotton fabric treated with the new compound $\left[\mathrm{Cu}_{2}(\mathrm{D})\left(\mathrm{NO}_{3}\right)_{4}\right]$ was assessed using a static immersion test reported in ATCC Technical Manual 2001. In this test, the amount of water absorbed by the fabric was measured. The cotton fabrics were weighed and immersed to a depth of $10 \mathrm{~cm}$ in a beaker with distilled water. The cotton fabrics were removed after $5 \mathrm{~min}$ and tapped to remove the excess water, and then weighed once again. The absorption was determined by the following formula: Absorption $(\%)=($ mass of water absorbed/original mass $) \times 100$ 
EPR structural investigations of $\left[\mathrm{Cu}_{2}(\mathrm{D})\left(\mathrm{NO}_{3}\right)_{4}\right]$

The EPR spectra of complexes were recorded using a Bruker EMXplus EPR spectrometer working in the X-band $(9.4 \mathrm{GHz})$ and temperature range of 120-450 K. The spectra simulation was accomplished within the software SIMFONIA (Bruker).

\section{Cell cultures and cultivation}

The human permanent cell line established from triple-negative breast cancer MDAMB-231 was used as a model system in the study. The cells do not express estrogen receptors either receptors for progesterone and HER-2/Neu receptors; they possess mutant p53 gene.

The cells have been grown as a monolayer culture in DMEM medium supplemented in the presence of $10 \%$ fetal bovine serum, $100 \mathrm{U} / \mathrm{mL}$ penicillin, and $100 \mu \mathrm{g} / \mathrm{mL}$ streptomycin. Thermo Scientific, HEPA Class 100 ) at $37 \mathrm{C}$ under $5 \% \mathrm{CO}_{2}$ in the air. For routine passages, the cells were detached using a mixture of $0.05 \%$ trypsin and $0.02 \%$ ethylenediaminetetraacetic acid (EDTA). The cell line was passaged 2-3 times per week (1:2 to 1:3 split).

\section{Cytotoxicity assays}

The cells were seeded in 96-well flat-bottom microplates for cell culturing at a concentration of $1 \times 10^{4}$ cells/well. After the cells were grown for $24 \mathrm{~h}$ to a sub-confluent state $(\sim 70 \%)$, the culture medium was removed and changed by media modified with different concentrations of the compounds tested. Each concentration was applied into 4-8 wells.

The effect of the compounds on cell viability/proliferation was assessed using MTT test after $24 \mathrm{~h}, 48 \mathrm{~h}$, and $72 \mathrm{~h}$ of incubation, neutral red uptake cytotoxicity assay (NR), crystal violet staining $(\mathrm{CV})$, and trypan blue dye exclusion test (TB) after $72 \mathrm{~h}$ of incubation.

The cell viability assay was performed by incubating the cells for 3 hours with a solution of $5 \mathrm{mg}$ MTT in $10 \mathrm{~mL}$ DMEM) at $37^{\circ} \mathrm{C}$ and $5 \% \mathrm{CO} 2$. The blue MTT formazan has been separated by extraction from ethanol and DMSO in a volume ratio of 1: 1 .

Cell viability is expressed as a percentage of the control and the corresponding curves depending on the concentration of the compounds were constructed. On this basis, the CC50 and / or CC90 values are also calculated where possible.

\section{Cytopathological changes}

The ability of compounds to induce cytopathological changes was assessed using double staining with acridine orange and propidium iodide (PI) as it was earlier described (Alexandrova et al., 2012). The cells were grown on coverslips (3.0-3.5 x 10 5 cells/well) in 6well plates in the presence of the tested compounds. Non-treated cells have been used as control. After $72 \mathrm{~h}$ of incubation, the coverslips were removed and washed with PBS for 2 min. Equal volumes of $10 \mathrm{mg} / \mathrm{mL}$ in PBS acridine orange and $10 \mathrm{mg} / \mathrm{mL}$ in bi-distilled water propidium iodide were added to the cells. The stained cells thus obtained were placed on a glass slide and examined by a fluorescence microscope (Leica DM 500B, Wetzlar, Germany).

\section{$3 D$ cell colony-forming method}

Tumor cells $\left(10^{3}\right.$ cells/well $)$ suspended in $0.45 \%$ agarose and D-MEM medium containing different concentrations of the compounds examined as well as culture medium control were layered in 24 well microplates. The presence/absence of colonies was registered 
using an inverted light microscope (Carl Zeiss, Germany) during a period of 20-32 days. Colony inhibitory concentration $(\mathrm{CIC}, \mu \mathrm{M})$ at which the compounds tested completely inhibited the 3D growth of tumor cells in a semi-solid medium was determined. The number of $3 \mathrm{D}$ cell colonies was counted in 3-5 independent fields for each compound/concentration.

Statistical analysis

Significant differences between experimental groups and control groups were evaluated by ANOVA followed by Dunnett's posthoc analysis. GraphPad Prism, GraphPadSoftware Inc., USA, 2000. The effective concentrations of the compounds $\mathrm{CC}_{50}$ and/or $\mathrm{CC}_{90}$ were estimated by Origin 6.1TM. 